\title{
Erratum to: HydrogeoSieveXL: an Excel-based tool to estimate hydraulic conductivity from grain-size analysis
}

\section{J. F. Devlin ${ }^{1}$}

Published online: 14 December 2016

(C) Springer-Verlag Berlin Heidelberg 2016

\section{Erratum to Hydrogeology Journal (2015), 23: 837-844 DOI:10.1007/s10040-015-1255-0}

In response to a Comment (Urumović and Urumović, 2016) regarding the original article (Devlin 2015), an error was noticed in Table 1. The Sauerbrei equation uses $d_{17}$ as the effective grain size (not $\left.d_{10}\right)$.

In the original article, the electronic supplementary material contained HydrogeoSieveXL version 2.0 (22 January 2015; Devlin 2015). The Reply to the Comment (Devlin 2016a) responded to the issues raised and expanded HydrogeoSieveXL in version 2.2 to include new information, dated September 2016 (at the time of publication of the Reply article).

The very latest version of HydrogeoSieveXL can be found on the University of Kansas (USA) website at https://kuscholarworks.ku.edu/handle/1808/21763, and any further updates will be executed on this website. Consistent with information given in the original article, the program will also be available on the author's webpage (Devlin, 2016b). The publisher assumes that the linked electronic supplementary material in Devlin (2015) was believed to be true and accurate at the date of publication and does not infringe any third party's rights. The publisher gives no warranty, express or implied, with respect to the material contained herein or for any errors or omissions that may have been made.

\section{References}

Devlin JF (2015) HydrogeoSieveXL: an Excel-based tool to estimate hydraulic conductivity from grain-size analysis. Hydrogeology Journal 23:837-844

Devlin JF (2016a) Reply to Comment on "HydrogeoSieveXL: an Excelbased tool to estimate hydraulic conductivity from grain-size analysis": technical note published in Hydrogeology Journal (2015) 23: $837-844$, by J. F. Devlin. Hydrogeology Journal, DOI 10040 10.1007/s10040-016-1510-z

Devlin JF (2016b) J.F.Devlin Homepage: Professor, Department of Geology, University of Kansas. http://www.people.ku. edu/ jfdevlin/Software.html. Cited November 2016

Urumović K, Urumović Sr (2016) Comment on "HydrogeoSieveXL: an Excel-based tool to estimate hydraulic conductivity from grain-size analysis": technical note published in Hydrogeology Journal (2015) 23: 837-844, by J. F. Devlin. Hydrogeology Journal, DOI 10040_10.1007/s10040-016-1509-5

The online version of the original article can be found at http://dx.doi. org/10.1007/s10040-015-1255-0.

J. F. Devlin

jfdevlin@ku.edu

1 Department of Geology, University of Kansas, Lindley Hall rm 120, 1475 Jayhawk Blvd., Lawrence, KS 66049, USA 